\title{
The Application of Stick Figures in Primary School English Teaching
}

\author{
Ying Wei \\ Foreign Language School \\ Huanghe Science and Technology University \\ Zhengzhou, China \\ E-mail: candy_weiying@yeah.net
}

\begin{abstract}
Stick figures are visually effective in words teaching, grammar teaching and texts teaching, which are widely applied in primary teaching. By supplying teaching material a lively and vivid circumstance, teachers can not only organize teaching procedure to gain better effects, but also satisfy children's learning psychology. Stick figures in English teaching have been proved efficient in arousing children' learning motivation and improve learning effects. This paper shows how stick figures work in teaching words, grammar, reading and some class activities in modern English teaching in primary schools.
\end{abstract}

Keywords-stick figures; application; primary English teaching

\section{INTRODUCTION}

For a long time, people are busy exploring a new and effective way of teaching English. Stick figures on the blackboard are usually rapid bur not accurate sketches, expressive like a caricature or drawings in humorous magazines. The best advantage of blackboard drawings is to make shapes or images directly explore to pupils. Teacher's drawing can penetrate into the mind of students with clarity and concentration. This rapid, lively drawing will get pupils highly involved in class activities.

This paper is to illustrate stick figures-a new and productive way of English teaching in primary schools. It first offers some information about the origin and development of stick figures in English teaching. Secondly, the actuality of stick figures in primary English teaching. Thirdly, stick figures are used in teaching words, grammar, reading and class activities. Last but not least, a conclusion arrives naturally: stick figures can be widely used in modern English teaching in primary schools.

\section{ORIGIN AND APPLICATIONS OF STICK FIGURES}

\section{A. The Origin of Stick Figures}

Some people hold the opinion that stick figures were invented by people who are not good at drawing. They also believe that stick figure's earliest roots are in the prehistoric art. Tens of thousands of years later, writing systems using images for words or morphemes (such as Egyptian and
Chinese), as linguistic symbols, started to simplify people and other objects. There is also a modern history that traces at least part from Rudolf Modley's extending the use of figures from isotopes for commercial use. The first international use of stick figures is in the 1964 Summer Olympics in Tokyo. Pictograms created by Japanese designers Masaru Katzumie and Yoshiro Yamashita formed the basis of future pictograms. In 1972, Otl Aicher developed the stick figures used in signage, printed materials, etc. for the 1972 Summer Olympics in Munich. Drawing on those and many other similar symbol sets in use at the time, in 1974 and 1979 AIGA (commissioned by the U. S. Department of Transportation ) developed the DOT Pictograms-50 public domain symbols for use at transportation hubs, large events, and other contexts in which people would know a wide variety of different languages. These symbols derived from them, are widely used today.

\section{B. Applications of Stick figures}

\section{1) In random drawing}

Over the years, stick figures have evolved into many different forms. Such as the torso-less stick figures and the headless stick figures. Stick figures show many emotions such as angry with a red head and thunder like hair, or sad face with two tears like two springs. They were also invented for kids who love to goof off in class.

2) In animation

Stick figures have been proven effective as a source of advertising entertainment and as a form of storyboarding and film publicity. Stick figures are often used in animation for creating animates. As film special effects, it is able to visually display the outcome of a scene by using stick figures, and save the money, time and effort at the same time.

\section{3) In English Teaching}

No matter how complex or complicated are things, they can be summarized as a simple combination of lines and dots. The features of stick figures are simple, easy to understand, vivid, and so on. And the characters of pupils are lively, naughty and absent-minded. There are some difficulties for students to concentrate as long as 45 minutes, so it's vital to find an effective way to teach pupils English. 
Combining drawing stick figures on the blackboard will have an unexpected result. "The simplest classroom aid of all is the blackboard. It has great possibilities for pictorial representation" (Richard C. Smith 129). Just like that, blackboard is the most convenient tool in teaching procedure, and taking good use of it can improve teaching level. The application of stick figures in primary English teaching can not only improve the quality of teaching but also develop pupils' learning effects. It is good for enhancing students' memory, inspiring students' thinking imagination, and at last reaching a multiplier effect of teaching.

The writer believes that each sentence can be represented as a picture, or action figures can be unmistakably demonstrated by the scenario. To use stick figures in teaching procedure will help students understand the structure of the sentences, and the environment of using the sentence. "The blackboard drawings which are built up like a living organism, in front of the class, have a special life of its own." (Richard C. Smith 132). There are two languages in English teaching: one is audio language, and the other is silent language. If a teacher only uses sound language in teaching the atmosphere of the whole class will become dull boring, and the result is always not very satisfying. While, if teachers apply stick figures in class, teaching procedures will be more colorful and attractive.

\section{The ACtuality OF Stick FIgURES IN TEACHING PUPILS ENGLISH}

\section{A. Development of Primary School English Teaching}

As early as 1862, English had been taught in class as a basic course. The Qing government issued a programmatic document which stipulated the purpose, requests, teaching time, teaching content, and simple teaching methods. With the nature of semi-feudal and semi-colonial, the development of education in old China was very slow. Since the foundation of People's Republic of China, there comes a new period of English teaching. A lot of schools have taken English as a major course in all levels of schools. In the following years, there is a flourish in English education.

In the last twenty years of $20^{\text {th }}$ century, teachers taught English only through books and asked students to recite by heart, but ignored pupils' language capacity. For many teachers, traditional "teacher-centered" model are deeply rooted in their mind. They transfer knowledge to students just like fed ducks, which does not allow students to practice.

\section{B. The Character of Pupils in Learning English}

Primary students are fast-learners of English than adults. They imitate teacher's pronunciation, sentences, phrases, and words more easily, and don't care about explicit grammar rules. An important prerequisite for effective learning should be activity-based, rather than explanation-or theory-oriented. And the activities are expected to be highly-involved. Use of audio-visuals is more important than the printed text. Language learning is encouraged in the classes and in all environments. Primary school pupils have a curiosity nature to investigate the environment in great detail. Teachers can create a bazaar inside the classroom for reading and conversation purposes. Situation teachings are greatly enjoyed by primary school pupils, and they actively participate in such games. Primary school pupils are interested in group activities, so some language-related tasks such as language games will be useful in teaching.

\section{Difficulties in Teaching Pupils English}

English taught, spoken, and written in the Third World countries are often not plain, simple, and straightforward. It is certainly needed to emphasize grammatical correctness, but cultivate in our learners' sensitivity and skill to use natural, simple English should be paid equal importance. And motivation affects cognition, since motivated individuals are more likely to be involved in effective learning and memory. Teachers will recognize the importance of promoting students in learning process and ensuring the existing motivation. Nowadays, more and more English teachers have realized it, and have been making their efforts to reform the traditional teaching. In modern English teaching, how to effectively encourage and motivate students to engage in their learning in the classroom is the main problem in primary school English teaching. Although classes often seem the same outwardly, differences between teacher-centered teaching and students-centered teaching are enormous. Students-centered teaching may have better effects since teachers try to stimulate the students to learn on their own by asking provocative questions posing problems, and most importantly, being an active participant; and students can be fully involved in teaching and learning activities. To sum up, students-centered teaching not only makes learning active and enjoyable, but also enables students to learn how to find and solve problems by themselves.

\section{Advantages of Stick Figures in Primary English Teaching}

"The best type of blackboard drawing is a rapid sketch, expressive like a caricature or the drawing in a good humorous magazine, but not necessarily accurate. The great advantage of a blackboard drawing is that it takes shape under the eye of the pupil." (Richard C. Smith 132). By using stick figures appropriately, language can be easily with the adventures of enriching the teaching procedure by increasing non-intellectuality factors in teaching. Painting is one of the fine arts of visual sight. Teachers transfer what's need to be learnt on the blackboard by simplified teaching stroke, bringing in students an exciting visual effect. "The blackboard, it has great possibilities for pictorial representation; for writing the lists of new words or paradigms on it." (N.R. Choudhury 8). Blackboard drawings are helpful in improving pupil's ability and developing students' potential and intelligence in English learning. Teachers can use stick figures in every situation, every types of lesson, and any content of courses. What's more, teachers can easily finish teaching plan to reach instructional objectives. As English is a second language for Chinese students, there are some abstract conceptions which are 
difficult to express, but if stick figures are used in teaching procedure, this problem will be solved. Because stick figures can change abstract concepts into concrete terms, make something difficult easy, develop students' divergent thinking ability and improve the ability of analytical and problem solving skills.

\section{APPLICATION OF STICK FigURES IN TEACHING PROCEDURE}

\section{A. Using Stick Figures in Teaching Nouns}

Communication in any language is impossible without some mastery of the words used in that language. Through the using of words can we compose and express our thoughts. Learning words in any second or foreign language program involves not only learning the meanings of the words, but also learning how these words are used appropriately in our daily communications or in linguistic, sociolinguistic, and cultural contexts. "The words alone may not sufficient to carry the pupils over into the imaginary situations for which the words are intended to build. Moreover, in order to make the entire teaching learning process of English language lively, interesting and comprehensible the teachers need to take the help of various device in the classroom teaching learning process." (N.R. Choudhury 125) to utilize stick figures on the teaching of nouns, verbs and prepositions, the process will be very simple.

\section{1) Teaching Nouns and Verbs}

When students learn some nouns and verbs, it may be easier for students to directly look at stick figures together with listening to the words. There is no translation from English to mother tongue, so the learning process will not be interfered by students' first language. The advantages of stick figures are to make pupils remember new lesson naturally and leave them a deep impression of the words. "But I was able to get their attention by drawing pictures of cats and inviting members of the class to outdo my cats, and then telling a jury to number the cats in order of excellence." (Richard C. Smith 133). When teaching the word "apple", if teachers teach pupils directly by translation and pronunciation, then students will associate their mother tongue and translate it into “苹果” firstly; but if teachers use stick figures to draw an image of apple on the blackboard then write the word "apple", students will associate the picture with the word naturally. At last students will have the ability of thinking in English by training again and again.

Verbs aren't showed as easy as nouns. But through this method, teachers can make students understand easily. When teachers want to teach students the words "up" and "down", they can draw some stairs and a person to describe "go up the stairs" and "go down the stairs". And teachers can imitate the action of "going up the stairs" and "going down the stairs". They can also let students do some actions about these verbs. Students thus can understand the words more profoundly. As for the word "listen", they can draw a radio, an earphone and some symbols of music on the blackboard can be drawn as stick figures, thus students will know that a person is listening to music. Like this, the study of verbs can be conducted by this method, and students can not only learn well, but remember well and use them in a good situation.

\section{2) Teaching Preposition}

In English learning, the usage of prepositions are difficult for students to grasp. "If the teacher is an expert in blackboard drawings, simple match stick diagrams can be used to create situations." (Nanda, V.K 259). There are many non-objective meanings of preposition, such as when learning "under" and "on". If teachers only teach the prepositions by mouth, it is very difficulty for students to understand what the meanings are and how to use them. But if teachers can draw a picture such as a cat under a table, or an apple on the desk then explain the usage of the two prepositions orally, it will be very easy for students to understand them. Another example: a stick figure of a tree that has a lot of apples on it, and another tree that has a bird in it, students can easily grasp the differences between "on the tree" and "in the tree". Stick figures can express what the preposition means, and give students a directive impression of words. Thus, The word "at" is hard for students to grasp, and it has so many usages that a student can't make it into practice at once. But the teacher can draw some pictures of station and there is a person and some bus staying there, which gives students a sense of instinct.. In this situation, students can use the word "at" to make a sentence. For example, Jane is waiting for you at the bus station. In this sentence, the teacher can analyze the usage of the word "at" to students, and they will not use it wrongly. Also the teacher can draw a house, a television and a person on the blackboard. Students will think about that there is a person is watching TV at home. Thus, students can use these preposition words intentionally and unintentionally.

The preposition "by" is also a challenge for the teacher to teach it well, but through stick figures such as a person, a bus and a scenery spot on the blackboard. And the teacher can let students make some sentences according to these pictures. Thus, some students may remember the word "by". A person wants to get the scenery spot, but how can he get there? He can get there by bus or by train or by air. Through this example, students learn the usage of "by". They will know that the word "by" can be used with some vehicles such as train, bus.

\section{B. Using Stick Figures in Teaching Grammar}

Learning words involves learning structures of the language, so students are encouraged to learn not only the words but also the grammatical rules. The application of stick figures in teaching English grammar will help build a lively classroom, bring a real context into the classroom, and enhance students' use of English.

By means of stick figures, teachers change the boring stuff sentence patterns and grammar teaching into a concrete, direct language learning process. When teaching comparative and superlative, it is very easy to understand by drawing three apples of different sizes. Write down "big" for the first one, "bigger" for the second one and "biggest for the last one. Then explain to students what the meaning of "comparative" and "superlative" are. Another example, 
drawing three children: the first one is taller than second one, the second one is taller than the third one, and write dawn "tall", "taller", "tallest" respectively under different child. In doing so, students can grasp the essentials breezily together with some exercises, and the result will be more perfect. Present Progressive is one of the most important tenses that students should learn, and at the same time it is hard to grasp. In spite that teachers emphasize for many times, there are still some students who cannot master the key points. When teaching this tense, the application of stick figures will facilitate students' understanding. "For creating situations, actions can be performed. It is done carefully by the teacher so as to create the right type of situations, for example, 'I am reading.' 'I am writing.' 'He is standing. He is sitting.' For all these sentences, situations are created by performing actions and thus they are taught to the students." (Nanda, V. $\mathrm{K}$ 259-8) Teachers can draw a person who is having a cup of tea in hand. With the help of this picture students are able to keep the useage of this tense in mind. "Uses of pictures for practicing the Tenses: One way to get plenty of practice of the tenses is to ask about what the people in the picture are doing, have done, will do a will have done in two hours time." (N.R. Choudhury 126-13) Through the pictures, teachers can also let students make sentences by practicing these tenses. For example, drawing a person who was standing near an apple on the blackboard, he can ask students: "This apple is on the desk. What is this person doing?" Students will answer: "He is going to eat the apple." Through practice, students can better master tenses; moreover, their speaking ability are also improved.

"This is a tree and it needs be irrigated." Teachers can draw a withered tree on the blackboard and let students have a discussion about how to irrigate it. Thus, students' enthusiasm is aroused. Then teachers can give more explanation of this tense or sentence structure to students.

\section{Using Stick Figures in Text Reading}

Since there are a great deal of contents and complex details in text reading, it is difficult for students to comprehend the whole structure, let alone grasp the main information. "The best way of teaching structures is by creating situations. The situation makes the structure easily understandable. It establishes a closer and more direct relation between an expression and its meaning." (Nanda, V. K 258-16) "Situational teaching means teaching by creating situations. Anything taught or learnt in a situation is more meaningful than other wise. It makes teaching or learning more realistic. Moreover, the learner is able to retain the matter for a longer time. Situational teaching is, therefore, of great value in the teaching of any language." (Nanda, V. K 258-10) By applying blackboard stick figures to create a simple situation, it is easy for students to grasp the main idea of the text. Students' thinking mode will be of great help to English teaching by the means of the using of visual aids. And there will be an improvement in students' learning efficiency. A recognition test from a group of students shows that the use of pictures have a good effect in keeping students' memories. In the following test, the students are divided into two groups: in group one, students get information from their teacher orally, three days later the retention of this group' students is only 10\%; in group two, students obtain the knowledge from their teacher both orally and looking at blackboard drawings, and three days later the retention of this group' students is astonishing $65 \%$. If the teachers can create some stick figures according to the content of the text in teaching procedure, it can not only increase students' interesting, but also activate their memories and help students retell the text that they have learned.

\section{Using Stick Figures in Class Activities}

Some students may have little interests in language learning because it is abstract, but the majority of them are showing great interest in visual pictures and drawing pictures themselves. If teachers can combine blackboard stick figures with language teaching by designing all kinds of games, the results will be excellent. For instance, teachers draw a stick figure on blackboard which is half-done (e.g. animals), and let students guess what the left half of the drawing will be, or what the drawings will be and so on. In doing this, students' curiosity will be greatly aroused, and their imagination will be stimulated; what's more, the environment of classroom will be activated and enlivened to reach a better learning effect.

In summary, stick figures are can create a teaching situation and language environment for classroom teaching with convenience and simplicity.

\section{CONCLUSION}

As teachers of $21^{\text {st }}$ century especially whose students are primary school pupils, it is indispensible to master professional skills or teaching aids such as the ability of drawing stick figures in teaching process to help students grasp English language efficiently. This paper mainly focuses on the application of stick figures in primary school English teaching from four different aspects: teaching words, teaching grammar, texts, and class activities. Pupils with an early age are lively, active and brisk; the majority of them have an interest in visual things. The application of stick figures will help attract primary school pupils' attentions effectively and make them focus on English learning. From all the above, it proves the contributions of stick figures in English teaching.

\section{REFERENCES}

[1] Gibert Grimes Weaver, Louis Cenci. Applied teaching techniques[M] Cornell University. Pitman Pub. Corp, 1960.

[2] Marlene D. LeFever. Creative Teaching Methods[M]. David C Cook, 1996.

[3] Nanda, V.K. Teaching Of English[M]. Publications Mehra Offset Press, Delhi: Anmol PVT. LTD, 2006.

[4] Namita.Roy. Choudhury. Teaching English in Indian Schools[M]. India at Efficient Offset Printers: APH Publishing, 1998.

[5] Richard C. Smith. Teaching English as a foreign language[M]. Great Britain: West and billows, 132.

[6] Rudolf Steiner, Walter Kugler. Blackboard drawings[M]. 1919-1924 Great Britain: Rudolf Steiner Press, 2003. 